\title{
EKSISTENSI KELUARGA DALAM PEMENUHAN HAK ATAS PENDIDIKAN ANAK DI MASA PANDEMI COVID-19
}

\begin{abstract}
Bambang Hadi Cahyono
IAIN Ponorogo

cahyonobambanghadi@gmail.com

Abstract:

This article aims to discuss the existence of families in fulfilling children's education during the Covid-19 pandemic. The existence of the Covid-19 pandemic has quite large implications in all aspects of life, both from economic, health, social, political and educational aspects. The government issued a policy regarding provisions in regulating education from school to home, in fact it caused various problems that were felt by both parents, especially for children. The existence of families, namely parents, both fathers and mothers, who initially paid less attention and education to their children because children have studied at school, now must provide more optimal care and education to maintain and increase children's learning motivation. Not only that, parents as teachers must also provide maximum education in order to create motivation in children to be able to carry out learning activities so that existing goals can be achieved even during the Covid-19 pandemic.
\end{abstract}

Keywords: Family existence, children's education, Covid-19 Pandemic

\begin{abstract}
Abstrak:
Artikel ini bertujuan untuk mendiskusikan tentang eksistensi keluarga dalam pemenuhan pendidikan anak dimasa pandemi covid-19. Adanya pandemi covid-19 cukup menimbulkan implikasi yang besar dalam segala aspek kehidupan, baik dari aspek ekonomi, kesehatan, sosial, politik serta pada aspek pendidikan. Pemerintah mengeluarkan kebijakan mengenai ketentuan dalam mengatur pendidikan dari sekolah ke rumah ternyata menimbulkan berbagai masalah yang dirasakan baik orang tua terlebih bagi anak. Eksistensi keluarga yakni orang tua baik ayah maupun ibu yang semula kurang memberikan perhatian dan edukasi terhadap anak karena anak telah belajar disekolah, kini harus lebih memberikan pengasuhan sekaligus edukasi yang optimal untuk menjaga dan meningkatkan motivasi belajar anak. Tidak hanya itu, orang tua sebagai guru juga harus memberikan edukasi yang maksimal agar terwujud motivasi dalam diri anak untuk dapat melakukan aktivitas belajar agar tujuan yang ada dapat tercapai meskipun pada masa pandemi covid-19.
\end{abstract}

Kata kunci: Eksistensi keluarga, pendidikan anak, Pandemi Covid-19

\section{PENDAHULUAN}

Keluarga adalah sebuah wadah bagi seseorang yang paling awal dalam melakukan proses interaksi sosial, yakni proses mempelajari karakter atau sifat yang dimiliki setiap orang yang ada disekitarnya. Selain itu, keluarga juga merupakan unsur terpenting dalam sebuah masyarakat, karena keluarga merupakan unit pertama sebelum memasuki kehidupan masyarakat. Sehingga masyarakat itu dikatakann baik jika keluarga-keluarga didalamnya adalah keluarga yang mempunyai pemahaman interaksi sosial yang baik. Dengan bahasa lain, keluarga ialah sebuah sarana yang mempunyai arti penting untuk pembentukan karakter, relasi dengan kerabat, sosial masyarakat serta kreativitas anggota-anggota didalamnya. ${ }^{1}$

\footnotetext{
$1 \quad$ Ulfiah, Psikologi Keluarga, (Bogor: Ghalia Indonesia, 2016), 1.
} 


\section{2 | Eksistensi Keluarga Dalam Pemenuhan Hak Atas Pendidikan}

Keluarga mempunyai peran yang cukup penting dalam dunia pendidikan anak, sebab keluarga tidak hanya digunakan untuk sarana tempat tinggal atau berteduh semata, lebih dari itu keluarga merupakan inti dari perkembangan manusia sejak ia lahir. Pada masa pandemi Covid-19 ini, eksistensi keluarga sangat dibutuhkan. Adanya pandemi covid-19 ini mengharuskan pembelajaran sekolah yang semula tatap muka menjadi sistem daring atau online. Terlebih lagi waktu yang dihabiskan oleh setiap anak jauh lebih banyak di rumah bersama orang tua dari pada di sekolah sehingga peran keluarga sangatlah dibutuhkan. Pada kenyataannya, pelaksanaan pembelajaran secara daring atau pendidikan jarak jauh belum berjalan dengan maksimal ${ }^{2}$, banyak hambatan yakni ketidaksiapan pendampingan orang tua dalam penjaminan kebutuhan belajar anak. Oleh karena itu sebuah keluarga harus menyiapkan dan melakukan upaya-upaya dalam menjamin dan meningkatkan kebutuhan belajar anak pada masa pandemi covid-19 ini.

Keberhasilan sebuah pendidikan merupakan tanggung jawab bersama, yakni dari sekolah, pemerintah serta dari keluarga yakni orang tua ${ }^{3}$. Jika melihat fakta yang ada dalam dunia pendidikan, pendidikan anak di negara Indonesia masih belum berjalan sesuai yang diinginkan, hal ini berdasarkan bukti masih banyaknya kasus kekerasan pada anak yang dilakukan oleh oknum pada masyarakat seperti: bullying, keasusilaan, kekerasan pada anak serta pngeksploitasian pada anak. Kasus tersebut pasti menimbulkan implikasi yang tidak baik pada anak, baik dari psikis, sosial, serta pada emosi anak. ${ }^{4}$

Fungsi keluarga yakni orangtua dalam mendampingi anak dalam proses pembelajaran dari rumah sangat berdampak pada motivasi belajar anak, agar potensi dan bakat anak tetap terbentuk ${ }^{5}$. Keaktifan orang tua ialah sebuah upaya secara langsung dalam memberikan edukasi pada anak tentang pembelajaran dan penciptaan lingkungan belajar yang menarik. Sebab sebuah rumah adalah lingkungan sosial yang paling awal yang dilalui oleh setiap anak. Selain itu, keluarga ialah wadah yang pertama bagi anak setelah ia dilahirkan ke dunia serta sebagai sarana anak untuk belajar sebelum mengarungi kehidupan. Pembelajaran itu dimulai dari bagaimana cara makan sampai anak mengarungi kehidupan dalam masyarakat. Sebuah keluarga adalah sarana yang cukup penting dalam upaya mengedukasi anak agar menjadi seorang individu yang siap hidup dalam masyarakat. Peran Orang tua dirumah adalah juga sebagai pelaksana pemberian dan pendampingan pembelajaran pada anak,

\footnotetext{
$2 \quad$ Selfi Lailiyatul Iftitah \&Mardiyana Faridhatul Anawaty, Peran Orang Tua dalam mendampingi anak di rumah selama pandemi covis-19, Journal of Childhood Education) Vol. 4 No. 2 Tahun 2020. 76 2016, 13.

Hatimah, Keterlibtn Keluarga dalam kegiatn di sekolh dalam perspektif kemitran, Bandung: Pedagogia,

4 Laily Fitriani, Membangun Pendidikan Ramah Anak Dalam Keluarga Di Era Pandemi Covid-19, Egalita: Jurnal Kesetaraan dan Keadilan Gender, Vol. 15, No. 1 2020, 3.

5 Ardiyana, R. D., Akbar, Z., Karnadi, K. Pengaruh keterlibatan Orang Tua dan Motivasi Intrinsik dengan Kepercayaan Diri Anak Usia Dini. Jurnal Obsesi: Jurnal Pendidikan Anak Usia Dini, 3(2), 494. Htpps:// doi.org/10.31004/obsesi.v3i2.253.
} 
yakni menjadi seorang guru seperti pada seorang guru yang ada di sekolah dengan melaksanakan setiap proses pembelajaran dan tugas yang disusun oleh sekolah. ${ }^{6}$

Keberhasilan sebuah keluarga sangat berpengaruh pada tumbuh kembangnya anak. Eksistensi orang tua dalam pendidikan anak sangat dibuutuhkan, yakni dengan memberikan pemahaman terhadap: pentingnya ilmu pengetahuan, tingkah laku, serta kemampuan bersikap kepada orang lain, seperti: budi pekerti, sopan santun, etika, rasa kasih sayang, rasa aman, dengan memberikan contoh yang baik agar anak membiasakan apa yang telah kita tanamkan dan contohkan. Peran orang tua yang sangat penting ini telah disepakati oleh berbagai pihak. Memberikan pengasuhan, pembinaan, serta pemberian pendidikan anak di tempat tinggal sendiri adalah sebuah keharusan bagi semua orang tua sebagai upaya pembentukan kepribadian anak. Pemberian pemahaman pada anak adalah sangat penting untuk pembentukan karakter anak. Dengan pemberian pemahaman atau edukasi yang baik, secara langsung akan memberikan rasa nyaman pada anak, karena anak merasa diperhatikan. Sehingga anak akan memiliki semangat belajar dan karakter anak akan terwujud.

\section{PEMBAHASAN}

\section{Teori Kemitraan Gender}

Kemitraan Gender terdiri dari dua kata kemitraan dan gender. Kemitraan berasal dari kata benda ke.mit.ra.an yang artinya perihal hubungan (jalinan kerjasama dan sebagainya) sebagai mitra. ${ }^{7}$ Secara istilah mitra berarti teman, sahabat, artner atau hubungan dua belah pihak yang saling menguntungkan. Sedangkan kata gender berasal dari bahasa Inggris gender yang berarti "jenis kelamin". Nasaruddin Umar mengatakan bahwa di dalam Webster's New World Dictionary, jender diartikan sebagai "perbedaan yang tampak antara laki-laki dan perempuan dilihat dari segi nilai dan tingkuh laku". Nasaruddin juga menjelaskan bahwa jender adalah konsep kultural yang berupaya membuat pembedaan (dictinction) dalam hal peran, perilaku, mentalitas, dan karakeristik emosional antara laki-laki dan perempuan yang biasanya digunakan untuk menunjukkan pembagian kerja yang dianggap tepat bagi laki-laki dan perempuan. ${ }^{8}$

Kemitraan Gender (gender partnership) adalah kerjasama secara eimbang atau setara dan adil antara suami, istri, anak laki-laki, dan perempuan dalam melakukan semua funsi keluarga dengan pembagian pekerjaan dan peran baik peran public, domestic, dan social masyarakat. ${ }^{9}$ Seorang suami dan istri yang bersama-sama bekerja, harus mampu bersikap dan bertindak luwes dalam melakukan pertukaran

Agustien Lilawati, Peran Orang Tua dalam Mendukung Kegiatan Pembelajaran Anak di Rumah pada Maa Pandemi, Jurnal Obsesi: Jurnal Pendidikan Anak Usia Dini, Vol. 5, Issue 1, 2020, 554.

7 https://kbbi.kata.web.id/kemitraan/, diakses 23 Juni 2021.

8 Nasaruddin Umar, Argumen Kesetaraan Gender Perspektif Alquran (Jakarta: Paramadina, 2001), 33-34.

9 Herien Puspitawati, Gender dan Keluarga: Konsep dan Realita Indonesia (Bogor: PT Penerbit IB Press, 2012), 243. 


\section{4 | Eksistensi Keluarga Dalam Pemenuhan Hak Atas Pendidikan}

tgas dan eran didalam semua aktifitas keluarganya, baik di sector public maupun dalam menjalani pekerjaan domestic di rumah. Suami istri dikatakan sukses menjalin sebuah hubungan yang baik, jika merka berhasil melakukan semua kewajiban di dalam kehidupan keluarganya secara bersama-sama saling mendukung dalam hal yang baik. ${ }^{10}$

Hubungan yang saling mempengaruhi atau adanya timbal balik antara suami istri sangat berguna untuk menjaga keselarasan hubungan keluarga, terutama dalam mewujudkan adanya pembagian peran, tugas, dan pekerjaan. ${ }^{11}$ Hubungan yang baik antara suami istri adalah kunci keharmonisan bagi sebuah keluarga. Wujud dari hubunga timbal balik itu adalah penyesuaian diri dari tugas dan peran antara suami dan istri akibat adanya kemitraan gender suami istri. ${ }^{12}$ Kemitraan gender ini meliputi pengelolaan sumberdaya keluarga, baik keuangan, pengambilan keputusan, dan bentuk kerjasama dalam keluarga lannya secara umum. ${ }^{13}$

Indikator adanya kemitraan gender (gender partnership) dalam keluarga adalah sebagai berikut: ${ }^{14}$

a. Kerjasama secara setara dan berkeadilan atara suami dan stri serta anak-anak bai laki-laki maupun perempuan dalam melakukan semua fungsi kekluarga melalui pembagian pekerjaan dan peran, baik peran public, domestic, maupun social kemasyarakatan.

b. Kemitran dalam embagian peran suami dan istri untuk mengerjakan aktivitas kehidupan keluarga menunjukkan adanya transparansi penggunaan sumber daya (tiada dusta diantara suami dan istri, tidak ada agenda rhasia, dan tidak ada udang di balik batu), terbentuknya rasa saling ketergatungan berdasarkan kepercayaan dan saling menghormati, akuntabilitas (terukur dan jelas0 dalam penggunaan sumber daya, dan terselenggaranya kehidupan keluarga yang stabil, harmonis, teratur yang meggambarkan adanya good governance di tingkat keluarga.

c. Kemitraan dalam pembagian peran suami istri berkaitan dengan kerjasama dalam menjalankan fungsi keluarga denggan kompnen perilaku mulai dari kontribusi ide, perhatian, bantuan moril dan materiil, nasehat berdasarkan pengetahuan yang didapat, sampai dengan bantua tenaga dan waktu.

d. Kemitraan gender disini merujuk pada konsep gender yaitu menyangkut perbedaan peran, fungsi, tanggungjawab, kebutuhan dan status social antara laki-laki dan perempuan berdasarkan bentukan/kontruksi dari budaya masyarakat; peran genderdi sini bukan kodrati, teta berdasarkan kesepakatan masyarakat; peran

\footnotetext{
10 Sri Lestari, Psikologi Keluarga:Penanaman Nilai dan Penanaman Konflik dalam Keluarga (Jakarta:Prenada MEDIA, 2016), 10.

11 Puspitawati, Gender dan Keluarga, 263.

12 Ibid.

13 Ibid.

14 Herien Puspitawati, Gender dan Keluarga Konsep dan Realita Indonesia (Bogor: PT Penerbit IPB ress, 2012), 208.
} 
social in dapat dipertukarkan dan dapat berubah tergantung dari kondisi budaya setempat dan waktu.

\section{Pengertian Keluarga}

Pada Kamus Besar Bahasa Indonesia menyebutkan bahwa keluarga adalah bermakna ibu, bapak dan anak-anaknya, serta mempunyai arti orang yang menjadi tanggungan dalam rumah tersebut. Sebuah keluarga ialah unit paling kecil dalam masyarakat yang memiliki fungsi sebagai sarana untuk mewujudkan kehidupan yang nyaman, tentram serta sejahtera yakni timbulnya rasa cinta serta kasih sayang terhadap para anggotanya. ${ }^{15}$

Sekumpulan manusia yang terdiri dari bapak, ibu dan anak-anak yang yang timbul akibat sebuah pernikahan, tinggal disuatu tempat serta memiliki peran-peran tertentu itulah yang dimaksud keluarga. Keluarga merupakan satuan masyarakat paling kecil yang menjadi sebuah inti dari sebuah masyarakat. Masyarakat dikatakan sejahtera, ketika keluarga-keluarga yang ada didalamnya juga sejahtera. Jika keluarga itu sejahtera, pasti masyarakatnya akan sejahtera. Namun sebaliknya, apabila keluarga itu tidak sejahtera atau miskin, maka dapat dipastikan masyarakat di lingkungan itu hidupnya tidak sejahtera.

\section{Peran dan Fungsi Keluarga}

Peran dan fungsi dari keluarga telah diatur dalam Peraturan Pemerintah Nomor 21 Tahun 1994, yang mengatakan bahwa peran dan fungsi keluarga adalah terdiri atas fungsi-fungsi: (1) Agama, (2) Sosial kebudayaan, (3) Cinta dan kasih sayang, (4) Perlindungan, (5) Reproduksi, (6) Sosialisasi dan pendidikan, (7) Ekonomi, dan (8) Pembinaan lingkungan. Selain itu, juga dikemukakan oleh Mattensich dan Hill (Zeitlin et al., 1995), bahwa fungsi keluarga adalah terdiri dari: fungsi pemberian jaminan kebutuhan jasmani, penjaminan pendidikan, pengakuan jika ada anggota keluarga baru dengan jalan prokreasi atau adopsi, mengontrol tingkah laku sosial serta seksual, penjaminan moral anak dengan mencarikan pasangan hidup pada anaknya, serta melepaskan anggota keluarga yang telah dewasa tersebut. Adapun menurut United Nation, peran keluarga terdiri dari: peran penguatan relasi suami istri, proses adopsi serta hubungan suami isteri, pemberian pengetahuan serta pendidikan anak, pemberian nama serta status, merawat anak, melakukan perlindungan pada anggota keluarga, rekreasi dan perawatan emosional, serta penukaran barang dan jasa. ${ }^{16}$ Fungsi keluarga terdiri dari ${ }^{17}$ :

\footnotetext{
15 Tim Penyusun Kamus Pusat Bahasa, Kamus Besar Bahasa Indonesia (Jakarta: Balai Pustaka, 2005), 536.

16 Herien Puspitawati, Fungsi Keluarga, Pembagian Peran dan Kemitraan Gender Dalam Keluarga, Bogor: PT IPB Press, 2013, 1.

17 Mufidah, Psikologi Keluarga Islam Berwawasan Gender, Malang: Maliki Press, 2013 42-45.
} 
6 | Eksistensi Keluarga Dalam Pemenuhan Hak Atas Pendidikan

1) Fungsi Biologis, yakni melanjutkan keturunan agar bisa memelihara martabat dan kehormatan sebagai makhluk yang berakal dan beradab yakni melalui pintu pernikahan. Fungsi inilah yang memberikan perbedaan manusia dengan makhluk lainnya karena sebab adanya aturan dan maksud dalam sebuah proses pernikahan.

2) Fungsi Edukatif, yakni fungsi yang harus ditunaikan sebuah keluarga untuk memberikan jaminan pembelajaran terhadap semua anggota keluarga. Yakni penjaminan pendidikan yang bisa ditempuh pada jalur formal maupun non formal. Namun pembelajaran itu juga bisa dimulai engan memberikan suri tauladan atau contoh yang baik pada setiap anggota keluarga dengan aturan atau kesepakatann yang dibuat dalam keluarga tersebut.

3) Fungsi religius, yakni fungsi pemberian nilai-nilai agama dalam sebuah keluarga yang harus diimplementasikan oleh seluruh anggota keluarga. Yakni dengan pengetahuan, pemahaman, sikap serta perilaku yang akan mewujudkan sifat sadar dalam prakti kehidupan sehari-hari.

4) Fungsi protektif, yakni fungsi perlindungan yang harus dihadirkan dalam sebuah keluarga. Keluarga sebagai tempat untuk melindungi dari bahaya apapun yang dapat mengancam jiwa dari setiap anggota keluarga.

5) Fungsi sosialisasi, fungsi ini merupakan pemberian pengetahuan dan pemahaman pada anak dan semua anggota keluarga agar dapat mennjadi anggota masyarakat yang baik. Keluarga mempunyai fungsi untuk mengedukasi anak dan anggota keluarga dengan memegang nilai-nilai kehidupan secara menyeluruh, yakni dengan memahami perbedaan-perbedaan yang sering muncul dalam kehidupan masyarakat bernegara.

6) Fungsi rekreatif, yang dimaksudkan adalah bahwa adakalanya dalam keluarga terdapat perbedaan-perbedaan pendapat dan keinginan dari setiap anggita keluarga. Sehingga fungsi ini hadir sebagai pemberian kesejukan ketika terjadi hal-hal demikian, sehingga terwujud relasi antar anggota keluarga yang harmonis, nyaman, tenteram, saling menghargai dan menghormati, serta para anggota keluarga nyaman tinggal dirumah karena surga dunianya adalah dirumah bersama keluarga.

7) Fungsi ekonomis, keluarga merupakan satuan ekonomis, yakni adanya kegiatan pemenuhan nafkah, pemeliharaan usaha, perencanaan keuangan, pengelolaan keuangan terhadap dana yang dipunyai keluarga, agar terwujud kemaslahatan setiap anggota keluarga yang bisa dipertanggungjawabkan harta benda yang dimilikinya secara moril dan spirituil.

Pemaparan diatas merupakan tujuh peran atau fungsi keluarga yang akan dihadapi oleh semua keluarga dimanapun ia berada. Tujuh fungsi keluarga diatas, wajib dijalankan supaya keluarga menjadi surga bagi para anggotanya. 
Eksistensi Keluarga dalam Pemenuhan Hak Atas Pendidikan Anak di Masa Pandemi

\section{Covid-19}

Pandemi covid-19 mengwajibkan semua orang untuk selalu mematuhi protokol kesehatan yang berdampak pada segala aspek kehidupan. Salah satunya adalah pendidikan pada anak, bahwa pembelajaran yang semula disekolah dialihkan secra daring atau online dari rumah mereka masing-masing ${ }^{18}$. Oleh sebab itu, dengan adanya pergantiansistem pembelajaran yang semula tatap muka disekolah berganti menjadi sistem daring atau online ini, mengharuskan keaktifak peran keluarga yakni orang tua sebagai kunci utama dalam keberhasilan pendidikan anak pada masa pandemi covid-19 ini. ${ }^{19}$

Pendidikan anak merupakan sebuah hal keharusan yang dilakukan oleh sebuah keluarga dalam menjalankan perannya. Sebab, fungsi keluarga tidak hanya untuk tempat tinggal semata, namun lebih dari itu ada peran yang harus dijalankan oleh sebuah keluarga sebagai pusat peradaban manusia sejak ia lahir ke dunia. Diantaranya ialah seperti: pengasuhan, pembinaan, dan pendidikan anak di rumah adalah keharusan yang dilakukan oleh orang tua untuk pembentukan kepribadian anak ${ }^{20}$. Terlebih lagi waktu yang dihabiskan oleh setiap anak jauh lebih banyak di rumah bersama orang tua dari pada di sekolah sehingga peran keluarga sangatlah dibutuhkan. Peran orang tua selama proses pembelajaran dirumah yakni memelihara dan meningkatkan motivasi belajar anak, mendampingi pembelajaran anak, meningkatkan kekreatifitasan anak serta mengevaluasi hasil belajar anak. ${ }^{21}$

Perkembangan pendidikan dalam sebuah keluarga sangat bergantung pada tingkat kesadaran hukum pada masyarakat terhadap pentingnya kebutuhan pendidikan pada anak. Oleh sebab itu, pemberian pemahaman ataupun edukasi dalam keluarga diharapkan bisa meningkatkan motivasi pendidikan anak untuk mewujudkan kebutuhan belajar anak. Karena keberhasilan pendidikan pada pendidikan formal maupun pendidikan nonformal juga didasarkan pada keberhasilan pendidikan pada keluarga. ${ }^{22}$

Jika melihat fakta yang ada dalam dunia pendidikan, pendidikan anak di negara Indonesia masih belum berjalan sesuai yang diinginkan, hal ini berdasarkan bukti masih banyaknya kasus kekerasan pada anak yang dilakukan oleh oknum pada masyarakat seperti: bullying, keasusilaan, kekerasan pada anak serta pngeksploitasian

18 Oktaria \& Putra, Pendidikan anak dalam keluarga sebgai strategi pendidikan anak usia dini saat pandemi covid-19, Jurnal Ilmiah Pesona Paud, 7(1), 2020, 41-51.

19 Wahyu Trisnwati, Pendidikan Anak dalam Keluarga Era Covid-19, Jurnal Obsesi: Jurnal Pendidikan Anak Usia Dini, Vol. 5 Issue 1, 2020, 825

20 Mutiah, Psikologi bermain Anak Usia Dini, Jakarta: Kencana, 2012.

21 Trisnadewi \& Muliani, Pembelajaran Daring di Masa Pandemi Covid-19. Yayasan Kita Menulis, 2020)

22 Ibid., 238. 


\section{8 | Eksistensi Keluarga Dalam Pemenuhan Hak Atas Pendidikan}

pada anak. Kasus tersebut pasti menimbulkan implikasi yang tidak baik pada anak, baik dari psikis, sosial, serta pada emosi anak. ${ }^{23}$

Lingkungan keluarga merupakan sarana yang sangat penting yang digunakan dalam keberhasilan sebuah pendidikan pada anak. Adanya pandemi covid-19 ini, mengharuskan anak untuk belajar dari rumah dan menghabiskan banyak waktu di rumah. Sehingga, kesiapan keluarga dalam menerapkan strategi pendampingan terhadap tumbuh kembang anak termasuk pada pendidikan anak menjadi sangat penting untuk diperhatikan. Hal ini dimaksudkan agar anak mendapat perlindungan serta dukungan dari keluarga dalam menjalani rutinitas belajar anak pada masa pandemi-19 ini dengan nyaman, tenteram serta damai ${ }^{24}$ oleh karena itu, tidak bisa dipungkiri bahwa eksistensi orang tua dalam pengasuhan dan pendampingan pada anak dalam pembelajaran pada masa pandemi covid-19 ini mempunyai implikasi atau dampak yang cukup signifikan pada pendidikan anak. ${ }^{25}$

Sebuah keluarga ialah pondasi atau dasar yang utama untuk keberhaslan pendidikan anak. Pemberian contoh tingkah laku dari orang tua secara tidak langsung akan membantu perkembangan potensi anak. Misalnya seperti contoh menghargai pendapat anak dan memberikan pemahaman pada anak bahwa berpendapat itu penting untuk disampaikan agar terjadi keterbukaan. Selain itu, orang tua dapat memberikan kesempatan anak untuk melakukan evaluasi diri, berpendapat, serta memberikan kesempatan pada anak untuk mengambil keputusan yang diharapkan akan memberikan dorongan pada dirinya supaya selalu bertanya. Sikap orang tua seperti pemberian pemahaman pada anak untuk berani mencoba hal-hal yang baru perlu ditanamkan oleh orang tua agar bisa menunjang keberhasilan pendidikan anak. Dengan demikian diharapkan anak akan merasa diperhatikan, karena orang tuanya sungguh-sungguh dalam mendampinginya belajar, menjadikan anak nyaman, serta keharmonisan dalam sebuah kerja sama antara orang tua dan anak. ${ }^{26}$

Ada beberapa usaha dalam mencapai keberhasilan pendidikan anak pada sebuah keluarga. Diantaranya dengan strategi pendampingan yang ramah dan baik serta anti kekerasan, yakni:

1) Jalinan komunikasi yang baik dan seimbang antara anak dengan orang tua. Komunikasi adalah sebuah alat untuk menyampaikan maksud dan tujuan dari setiap individu. Dengan komunikan yang baik, akan tercipta keterbukaan antara orang tua dengan anak. Keberhasilan pendidikan anak akan terbantu dengan jalinan komunikasi yang baik antara orang tua dengan anak.

2) Menerapkan pola pengasuhan yang ramah terhadap anak. Artinya, orang tua tidak boleh melakukan tindak kekerasan dalam pemenuhan pendampingan pendidikan

23 Laily Fitriani, Membangun Pendidikan Ramah Anak Dalam Keluarga Di Era Pandemi Covid-19, Egalita: Jurnal Kesetaraan dan Keadilan Gender, Vol. 15, No. 1 2020, 3.

24 Fitriani, Op. Cit., 17.

25 Lestari, Pendidikan Anak Usia Dini di Masa Pandemi Covid-19, Yayasan Kita Menulis, 2020.

26 Agustien Lilawati, Peran Orang Tua Dalam Mendukung Kegiatan Pembelajaran di Rumah pada Masa Pandemi, Jurnal Obsesi: Jurnal Pendidikan Anak Usia Dini, Vol. 5 Issue 1 2021, 552. 
pada anak. Hal ini dimaksudkan agar anak merasa dilindungi dan didukung dengan adanya keberadaan orang tuanya.

3) Pentingnya peran kekluarga dalam memberikan pemahaman pada anak tanpa dibarengi dengan tindak kekerasan pada anak. Hal ini dimaksudkan agar terbentuk emosional dan psikis yang baik pada perkembangan anak. Implementasi perwujudan kepribadian yang baik pada anak ini memerlukan sebuah model pengasuhan yang baik dengan pemberian teladan atau contoh yang baik pula dari orang tuanya. Seperti yang disampaikan oleh Yosada dan Kurniati, bahwa dalam membentuk kepribadian yang positif perlu adanya contoh atau teladan dari orang tua, yitu diantaranya: pemahaman rasa empati, tidak boleh adanya diskriminasi, tidak boleh bersikap radikal, harus mencintai negara dan bangsa, penghargaan terhadap HAM, menghormati sesama manusia tanpa melihat perbedaan ras, suku, bahasa serta tidak merendahkan sesama. Dengan demikian keberhasilan pendidikan anak akan terwujud, sebab anak akan memahami dan sadar dengan sendirinya bagaimana ia bersikap nantinya dan hidup dalam masyarakat luas ${ }^{27}$.

\section{PENUTUP}

Dari paparan singkat diatas dapat disimpulkan bahwa: eksistensi orang tua dalam pendidikan anak sangat dibutuhkan, yakni dengan memberikan pemahaman terhadap: pentingnya ilmu pengetahuan, tingkah laku, serta kemampuan bersikap kepada orang lain, seperti: budi pekerti, sopan santun, etika, rasa kasih sayang, rasa aman, dengan memberikan contoh yang baik agar anak membiasakan apa yang telah kita tanamkan dan contohkan. Keluarga mempunyai peran yang sangat vital dalam pendidikan anak, sebab keluarga tidak sekedar untuk sarana tempat tinggal, namun keluarga adalah wadah sebagai inti dari peradaban manusia sejak ia lahir ke dunia. Sehingga pada masa pandemi Covid-19 ini, eksistensi keluarga sangat dibutuhkan. Sebab, adanya pandemi covid-19 ini mengharuskan pembelajaran sekolah yang semula tatap muka sekolah menjadi sistem daring atau online dari rumah.

\section{DAFTAR RUJUKAN}

Ardiyana, R. D., et. Al. 1999. Pengaruh keterlibatan Orang Tua dan Motivasi Intrinsik dengan Kepercayaan Diri Anak Usia Dini. Jurnal Obsesi: Jurnal Pendidikan Anak Usia Dini. Volume 3 Nomor 2.

Fitriani, Laily. 2020. Membangun Pendidikan Ramah Anak Dalam Keluarga Di Era Pandemi Covid-19. Egalita: Jurnal Kesetaraan dan Keadilan Gender. Volume 15 Nomor 1.

${ }_{27}$ Yosada \& Kurnia, Mencipakan sekolah ramah anak, Jurnal Pendidikan Dasar Perkhasa, 5 (2) Oktober 2019, 150. 
10 | Eksistensi Keluarga Dalam Pemenuhan Hak Atas Pendidikan

Hatimah. 2016. Keterlibatsn Keluarga dalam kegiatan di sekolah dalam perspektif kemitran. Bandung: Pedagogia.

Iftitah, Selfi Lailiyatul dan Mardiyana Faridhatul Anawaty. 2020. Peran Orang Tua dalam mendampingi anak di rumah selama pandemi covis-19. Journal of Childhood Education) Volume 4 Nomor 2.

Lestari. 2020. Pendidikan Anak Usia Dini di Masa Pandemi Covid-19. Yayasan Kita Menulis.

Lestari, Sri. 2016. Psikologi Keluarga:Penanaman Nilai dan Penanaman Konflik dalam Keluarga. Jakarta:Prenada MEDIA.

Lilawati, Agustien. 2020. Peran Orang Tua dalam Mendukung Kegiatan Pembelajaran Anak di Rumah pada Maa Pandemi. Jurnal Obsesi: Jurnal Pendidikan Anak Usia Dini Voume 5 Issue 1.

Lilawati, Agustien. 2021. Peran Orang Tua Dalam Mendukung Kegiatan Pembelajaran di Rumah pada Masa Pandemi. Jurnal Obsesi: Jurnal Pendidikan Anak Usia Dini. Volume 5 Issue 1.

Mufidah. 2013. Psikologi Keluarga Islam Berwawasan Gender, Malang: Maliki Press.

Mutiah. 2012. Psikologi bermain Anak Usia Dini, Jakarta: Kencana.

Oktaria \& Putra. 2020. Pendidikan anak dalam keluarga sebgai strategi pendidikan anak usia dini saat pandemi covid-19. Jurnal Ilmiah Pesona Paud, Volume 7 Nomor 1.

Puspitawati, Herien. 2013. Fungsi Keluarga, Pembagian Peran dan Kemitraan Gender Dalam Keluarga. Bogor: PT IPB Press.

Puspitawati, Herien. 2012. Gender dan Keluarga Konsep dan Realita Indonesia. Bogor: PT Penerbit IPB ress.

. 2012. Gender dan Keluarga: Konsep dan Realita Indonesia. Bogor: PT Penerbit IB Press.

Rahman, Misran. 2015. Pendidikan Keluarga Berbasis Gender. Musawa, Volume 7 Nomor 2.

Tim Penyusun Kamus Pusat Bahasa. 2005. Kamus Besar Bahasa Indonesia. Jakarta: Balai Pustaka.

Trisnadewi \& Muliani. 2020. Pembelajaran Daring di Masa Pandemi Covid-19. Yayasan Kita Menulis.

Ulfiah. 2016. Psikologi Keluarga. Bogor: Ghalia Indonesia. 
Eksistensi Keluarga Dalam Pemenuhan Hak Atas Pendidikan | 11

Umar, Nasaruddin. 2001. Argumen Kesetaraan Gender Perspektif Alquran. Jakarta: Paramadina.

Wahyu, Trisnawati. 2019. Pendidikan Anak dalam Keluarga Era Covid-19. Jurnal Obsesi: Jurnal Pendidikan Anak Usia Dini. Volume 5 Issue 1.

Yosada \& Kurnia. 2021. Mencipakan sekolah ramah anak. Jurnal Pendidikan Dasar Perkhasa, Volume 5 Nomor 2 (2019). https:/ / kbbi.kata.web.id/kemitraan/. 